\title{
Circuit
}

Musiques contemporaines

\section{Darmstadt as Refectory (Mess Hall)}

\section{John Rea}

Volume 15, numéro 3, 2005

Souvenirs de Darmstadt : retour sur la musique contemporaine du dernier demi-siècle

URI : https://id.erudit.org/iderudit/902372ar

DOI : https://doi.org/10.7202/902372ar

Aller au sommaire du numéro

\section{Éditeur(s)}

Les Presses de l'Université de Montréal

ISSN

1183-1693 (imprimé)

1488-9692 (numérique)

Découvrir la revue

Citer cet article

Rea, J. (2005). Darmstadt as Refectory (Mess Hall). Circuit, 15(3), 73-77.

https://doi.org/10.7202/902372ar

\section{Résumé de l'article}

Présent au cours de 1984 après une résidence à Mannheim, le compositeur canadien relate une série d'anecdotes au cours desquelles, il est étonné d'être (ou de ne pas être) reconnu comme l'auteur d'un Pincer la musique aujourd'hui au titre remarqué. Il évoque ensuite un concert de musique de Xenakis auquel il a assisté en compagnie de Morton Feldman, qui lui fit des confidences passablement intimes. S’ensuivent quelques réflexions plus générales sur le Darmstadt de sa génération et sur celui d'aujourd'hui.
Ce document est protégé par la loi sur le droit d'auteur. L’utilisation des services d'Érudit (y compris la reproduction) est assujettie à sa politique d'utilisation que vous pouvez consulter en ligne.

https://apropos.erudit.org/fr/usagers/politique-dutilisation/ 


\section{Darmstadt as Refectory (Mess Hall)}

John Rea

At once both less and more than what I expected, the Ferienkurse of 1984, the $32^{\text {nd }}$ edition, brings to mind two stories. As it happens, since January, that year I had been living in Mannheim at the Alte Feuerwache, a kind of Maison de la culture, not too far away in point of fact, geographically speaking at least, from Darmstadt. It was my second longest sojourn in Germany after Berlin (197980), and I found myself the recipient of a composer-in-residence stipendium, an initiative of the then director of Mannheim's Kulturamt, Dr. Siegfried Gerth, a visionary administrator. His annual four-month Kulturtage festival had taken a look in 1981 at its first extra-European nation, Canada, and he specifically requested that new concert music by young composers and performers also be heard. Luck would have it that some of my music was played, and I even received an invitation to attend the festivities. From this encounter, a proposal to live in Mannheim in the not-too-distant future, to be inspired by its renowned musical history and by what remained of its beauty (over half of the city had been destroyed during wwII) was made to me. It was a flattering proposal, and now here I was in 1984 living in a stylishly renovated $19^{\text {th }}$ century fire station, at the top of an elongated hose tower, housed in a circular loft with a view of the baroque town below rationally laid out in a chessboard pattern. Since 1606 , in the absence of street names, any destination or excursion obliged pedestrians to 


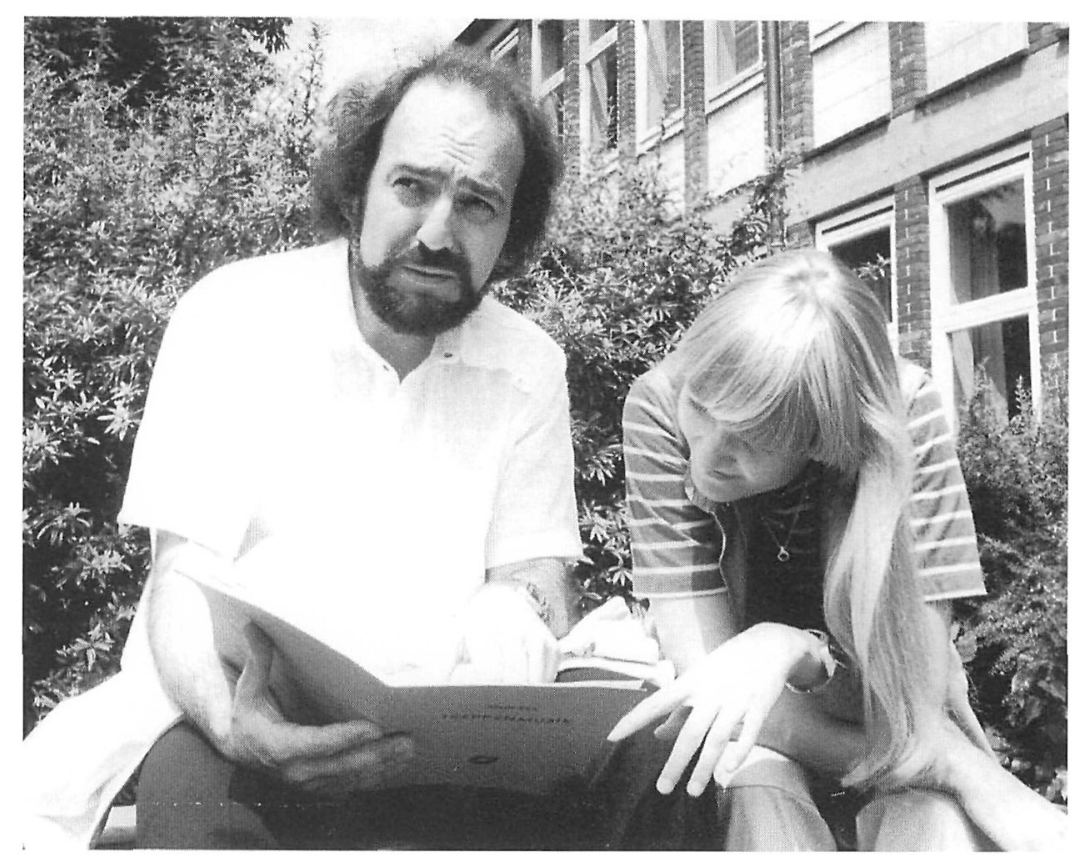

John Rea and a student examining the score of his work Treppenmusik, Darmstadt 1984.

It was with this personal anecdote recounted within the pious atmosphere of the Georg-Büchner Schule lunch room one day after my arrival at Darmstadt that I introduced myself to a young stranger who had taken the initiative to ask me - first in hesitant German then in an idiomatic and robust French (seeing that I was sitting across a monastic table from him, as he fidgeted with morsels of potato salad, ingesting a yellow globule now and then) just how it was that I had decided to attend this year's Ferienkursen. Lunches and dinners, I came to understand, were almost as important as concerts and lectures for the interpretation of valuable information. In any event, the possibility of being linguistically at ease reassured him even though, curiously, we never exchanged our names. We continued to talk and to eat our meals, turning our attention to previous summer courses, those of 1980 and 1982 , when the composers of L'Itinéraire, Gérard Grisey, Michaël Lévinas, Tristan Murail had been featured. True, Brian Ferneyhough and Wolfgang Rihm seemed like permanent luminaries at Darmstadt, as did Belgian musicologist, Harry Halbreich, but my anonymous interlocutor felt that 1984 might not be such a great year because Americans were de retour. By this he meant that both Earle Brown and Morton Feldman were expected as well as younger composers, Peter Garland, John McGuire, Tom Johnson and Robert Moran. 
Harry Halbreich, as I came to learn later in the autumn, had spent some weeks during the spring in Montreal researching an article about the active contemporary music scene, the city as "spectacle de l'effervescence esthétique et intellectuelle la plus réjouissante"l "Montréal: ça barde toujours"2, Le Monde de la Musique, $\mathrm{N}^{\circ} 71$, octobre 1984). My name would figure twice in his text, first where he writes: “Et, lorsque j’ai été séduit par la musique de John Rea, j'ai aussitôt appris que cet anglophone d'origine était depuis de longues années Montréalais d'adoption."3 Then, at the very end, speaking graciously about three of my works, he closes the article with: "Et l'humour ne perd pas ses droits, comme en témoigne le titre d'une récente [1981] pièce pour guitare, mandoline, harpe, clavecin, etc.: Pincer la musique aujourd'hui. À prononcer avec l'accent du cru en 'pensant' à Boulez..."4

Now I do not know whether it was due to the gastronomical inadequacies of the Ferienkurse lunch room, or to the absence in 1984 of Gallic musical sensibilities, or to my story about Mannheim ("Is any new music going on there?", the stranger asked), but something prompted my fortuitous mealtime partner to vent his spleen, for in learning that I was from Montreal where I mentioned Tristan and Gérard had visited on occasion, with frank disdain coupled with an uncanny grasp of Canadian music history, he declared: "Il paraît qu'à Montréal il y a un connard, vachement dingue, qui a composé une œuvre dont le titre fait bêtement allusion à la pensée boulezienne, et dont il n'a évidemment pas la moindre espèce d'idée - Pincer la musique aujourd'hui. Quelle honte!"s Taken aback - for how could he possibly possess such a musicologically recondite tidbit, I quickly regained my composure, and with a confidence that for all its imperial poise and tone even surprised me, I replied: "Monsieur, le connard, c'est moi!"6 whereupon he swallowed his final smidgen of yellow and obligingly withdrew from the table. I never saw him again in the entire three weeks.

The arrival of Morton Feldman (1926-1987) was for me a little like seeing an old friend because during the late 70 's and early 80 's he often visited Montreal "to eat Chinese food", as he would bellow in that unmistakable Manhattan accent, and I often accompanied him on those culinary excursions where he always enjoyed General Tao's chicken. Now, in Darmstadt, there were no Chinese restaurants to speak of. All the same, he was anticipating the European premiere of his four-and-a-half hour String Quartet $N^{\circ} 2$ (1983), which had recently been given its premiere by the Kronos Quartet in a live-to-air СBC broadcast from Toronto, and the same musicians were here to perform it again. Early on in the performance at the Orangerie, say about 45 or 50 minutes into it, Irvine Arditti and one or two other members of his quartet discreetly left the hall only to return two-and-a-half hours later. They had gone to eat dinner at
1. "supremely joyful spectacle of aesthetic and intellectual effervescence".

2. "Montreal: sparks are always flying".

3. "And immediately upon being seduced by the music of John Rea, I learned that this native anglophone had long been an adopted Montrealer."

4. "And since humour is always welcome, as witness the title of a recent [1981] piece for guitar, mandolin, harp, harpsichord, etc.: Pincer la musique aujourd'hui. * To be uttered in the local patois, while 'thinking', of Boulez..." * Translated literally as "Plucking music today" - a play on the word "Penser", meaning "To think", used in the sense of "Thinking music today" the translated name of a 1971 book by Boulez [Pensez la musique aujourd'hui].

5. "Evidently in Montreal there is a damned fool, a real loonie, who composed a work where the title makes silly allusion to Boulezian thinking, which he obviously doesn't have the faintest idea about. It's outrageous!"

6. "Sir, that 'damned fool' is me!" 
a steakhouse and were now leisurely smoking big cigars in the outdoor foyer listening and waiting for the masterful finale. Morton hadn't noticed a thing.

The Arditti Quartet also gave concerts that year, one of which was especially memorable because, among other things, Morton wanted to sit next to me, and because Tetras (1983) by Iannis Xenakis (1922-2001) was being done, and Morton hadn't yet heard it. I had attended a performance in late 1983 at the ISCM (Aarhus, Denmark) so I knew exactly what to expect. From the very downbeat - a staggering one at that, Morton began to lean over to me and every so often while the piece plunged forward would say in what can only be described as a bellowing whisper, certainly disturbing nearby listeners and making me an uneasy interlocutor, "Now howz hee gonna get outer dat?" Or, at thunderous, jabbing and fiery moments (abundant as they are in Xenakis), "Datz fantaaastic!" Or at a particularly epiphanous passage, "Uh, heez gettin' betta. Wealy, heez gettin' betta ' $n$ ' betta!" Needless to say, Morton Feldman had thoroughly enjoyed the work although I did find his reaction somewhat puzzling, coming as it was from a composer of some of the century's most diaphanous music.

Since this had been an early afternoon concert, he suggested that we have an early dinner. Seeing as I had a car, we drove at my suggestion to a nearby Italian eatery frequented by the students (no Chinese food, after all), and as I let him out near the front door entrance, for I had to park at quite some distance, I noticed - first in my rear view mirror then from my parking spot - that from out of nowhere a tall, well-endowed, mature woman was, with her arms around his neck, giving Morton a lengthy kiss on the lips. Putting the car keys in my pocket, I walked slowly back towards the restaurant where Morton had already entered waving goodbye to this mysterious apparition. I joined him at the table, we placed our orders, shared some wine and then began to eat. Midway through dinner, Morton (who was known to be myopic) looked up at me and said, 'You're probably wonderin' who dat lady was." As best as I could I feigned ignorance. He continued, "Well, sheez a forma gurlfriend ... from New Yawrk ... interestin' musician." We resumed eating our spaghetti whereupon he unexpectedly surged forward with: "I ask'd hur once, after an evenin' of lovemakin': 'So, was I good?' ... a stupid question, I know. Well, you'll neva imagine what shee said to mee afta a few dweamy moments: 'Ah, you're definitely betta than Lukas Foss [b. 1922-] but you're not as good as ... Xenakis!" ".

What does Darmstadt represent today? Probably it no longer attracts as it once did to its sanctuary the 'high priests' of composition nor the 'holy men' of musicology such as Carl Dahlhaus - assuming that, in our time, there are high priests and holy men to be attracted. The postwar years appear to us now like a golden era, with its then prevailing notion of a musical brotherhood regulated 
by a world government (located at Darmstadt), facilitated by a corresponding compositional 'Esperanto'. The immediate next generation, mine, was characterized by the fraternal use of electro-acoustic gadgets within musical monasteries (such as Ircam) and the communal notion of timbre as a metaphor for composition. By that time, however, Darmstadt could only stand by and welcome the arrival of visiting 'monks' from Paris, preaching their new orthodoxies. Today, an evident deconsecration both of the idea of sanctuary and that of gadget results as a consequence of the proliferation of the computer (the all-consuming idol of a new heretical religion?); since every person uses one, every person stays at home, or if not, goes to work and pray in another city, Hollywood. For me, the idea of Darmstadt remains linked to the idea of an abbey or a priory where ascetic, austere practices have always been a part of its Divine Office, be it integral serialism or the new complexity. Fewer and fewer young men, unfortunately, are taking holy orders. Then again, perhaps Darmstadt has only ever been an Internationale Messe für heilige Ton und Klang. 